\title{
Review
}

\section{Current Concepts in Cancer Vaccine Strategies}

BioTechniques 30:170-189 (January 2001)

\author{
Behjatolah Monzavi-Karbassi \\ and Thomas Kieber-Emmons \\ University of Pennsylvania, \\ Philadelphia, PA, USA
}

strategy for future vaccine development.

\section{INTRODUCTION}

The application of immunotherapeutic principles to the treatment and prevention of cancer has a rich heritage $(2,88)$. The recent definition of tumorspecific immunity in cancer patients and the identification of tumor-associated antigens (TAA) have generated renewed enthusiasm for the application of immune-based therapies to the treatment of malignancies $(21,38,85,119$, 149). Recent developments in cancer vaccines have also been based on an improved understanding of the cellular interactions required to induce a specific antitumor immune response $(12,15,30$, $71,85,142)$. Consequently, a number of cancer vaccine strategies have entered clinical testing $(24,40)$. The breakneck pace at which formulations are being tested precludes a thorough review of all strategies. Subsequently, this brief review touches upon ideas being pursued with representative examples for illustrative purposes in defining current perspectives and future strategies for active specific immunotherapy of cancers.

\section{OVERVIEW OF CANCER VACCINE STRATEGIES}

There are many ways to treat cancer. In general, immunotherapy can be considered either nonspecific, such as a general immunomodulator (e.g., a cytokine), or tumor-specific (e.g., a vaccine that targets tumor antigens). Table 1 defines representative approaches to developing cancer vaccines. Early concepts were initially based on nonspecific approaches using as examples bacterial agents that included bacillus Calmette-Guérin (BCG). Clinical trials in bladder cancer therapy evaluating these nonspecific agents or their products have proved BCG in particular to be promising for promoting a superior reduction in tumor recurrence compared with chemotherapy $(86,98)$.

Since the nature of TAAs was unknown for a long time, many of the initial clinical studies of specific tumor vaccines involved using whole tumor cells as a source of TAAs $(39,108,168)$. Melanoma is the most immunogenic solid tumor in humans and, as such, has served as the major model for tumor vaccine investigation in both the laboratory and the clinic $(26,57)$. The most extensively studied melanoma vaccines in clinical trials are whole-cell preparations or cell lysates that contain multiple antigens capable of stimulating an immune response. Unfortunately, in the majority of studies, immune responses to these vaccines have not translated into a survival advantage (57).

Advances in tumor cell immunology have led to the identification of candidate tumor cell antigens that represent a diverse array of structures associated with tumor cells or tumor rejection antigen (122). This, in turn, has allowed for refinements in vaccine design. However, the exact tumor antigens that should be targeted with a specific vaccine are unknown. As current concepts have been directed toward the induction of cellular immunity, cytotoxic $\mathrm{T}$ cell responses (CTL), peptides derived from human tumor antigens, have been used in particular in a number of clinical trials to induce specific immune responses against autologous tumor in cancer patients (112). Optimization of tumor T cell reactive peptides (35) might be determined by considering interactions of $\mathrm{T}$ 
Table 1. Representative Vaccine Types Explored for Cancer Immunotherapy

\begin{tabular}{|c|c|c|c|c|}
\hline Vaccine & Antigen & Adjuvant/Carrier & Cancers & References \\
\hline \multicolumn{5}{|l|}{ Nonspecific Approaches } \\
\hline $\begin{array}{l}\text { Viral oncolysates of allogenic } \\
\text { or autologous tumor cells }\end{array}$ & unknown & $\begin{array}{l}\text { Vaccinia virus, } \\
\text { Newcastle disease virus }\end{array}$ & $\begin{array}{l}\text { melanoma, ovarian } \\
\text { colorectal }\end{array}$ & $18,47,70,148$ \\
\hline Tumor cell extracts & unknown & $\begin{array}{l}\text { Detox, Antigen } \\
\text { presenting cells }\end{array}$ & melanoma, lung & $42,107,111$ \\
\hline \multicolumn{5}{|l|}{ Tumor-Specific Approaches } \\
\hline Anti-idiotype & $\begin{array}{l}\text { B-cell idiotype, } \\
\text { proteoglycans, } \\
\text { P97, ganglisosides }\end{array}$ & $\mathrm{KLH}$ & $\begin{array}{l}\text { melanoma, colon, ovarian, } \\
\text { breast, lymphoma, prostate }\end{array}$ & $\begin{array}{l}17,45,46,52 \\
169\end{array}$ \\
\hline $\begin{array}{l}\text { Synthetic } \\
\text { carbohydrate antigens }\end{array}$ & $\begin{array}{l}\text { TF, Tn, sialyl-Tn, } \\
\text { gangliosides, } \\
\text { Globo H, LeY }\end{array}$ & $\mathrm{KLH}$ & $\begin{array}{l}\text { breast, ovarian, melanoma } \\
\text { colon, pancreatic }\end{array}$ & $\begin{array}{l}3,32,37,64, \\
95,106,132 \\
152\end{array}$ \\
\hline
\end{tabular}

cell receptors with peptide displayed on libraries (113) or sequence motifs that affect major histocompatibility complex (MHC) haplotype binding (145).

Peptide and cDNA phage display libraries can be used to determine the specificity of antibodies present in whole sera of patients where information about the parental antigen is unknown. In this respect, patient serum antibody-binding ligands have been identified $(58,150,165)$. Such ligands would facilitate the design of diagnostic assays and therapeutic vaccines. In the case of cancer, this novel technology is expected to improve our understanding of the immune responses against tumor cells and to discriminate between autoantigen and true tumorspecific antigens.

Clinical trials with single peptides have been disappointing, and multiple peptide delivery is more encouraging, although help in the form of cytokine and dendritic cell (DC) presentation seems necessary $(80,116,153)$. On melanoma cells, autologous protein antigens that are potential targets in- clude Melan-A, MART-1, gp100, tyrosinase, TRP-1, and TRP-2 melanoma differentiation antigens, and MAGE-1, MAGE-3, and ESO-1 cancer testis (CT) antigens (137). Cell-mediated immunity and humoral immune reactivity have been demonstrated against autologous antigens on adenocarcinomas (i.e., breast, lung, gastric, and pancreas cancers). These antigens include CEA, HER-2/neu, MAGE-1, p53, MUC-1 $(56,159)$, prostate-specific antigen (PSA) (69) produced by prostate cancers, and alpha-fetoprotein (AFP) produced by liver cancers (hepatomas). Immunization of cancer with anti-idiotypic antibodies mimicking a variety of tumor antigens has also seen resurgence $(19,41,139)$.

Among autologous proteins, the use of tumor-derived heat shock/chaperone proteins (HSPs) as anticancer vaccines is gaining wider study and acceptance $(62,104,170,173)$. Heat shock proteins promote cell survival under adverse environmental conditions. HSPs have been correlated with tumor progression, promoting resistance to both che- mical- and radiation-induced apoptosis (50). Consequently, apoptosis remains a significant problem in the treatment of some cancers. HSP expression inhibits apoptosis as mediated by the production of survival factors such as Mcl-1, Bcl-2, Bcl-X(L), and glutathione-S-transferase (GST) $(22,50)$.

Heat shock protein-based vaccines have been shown to immunize against cancer and infectious diseases in both prophylactic and therapeutic protocols (155). So far, four classes of HSP preparation-gp96, HSP90 (hsp86, hsp84), HSP70 (hsc70, hsp70), and calreticulin-have been used successfully in tumor models. Vaccination of inbred mice with tumor-derived stress proteins hsp70, hsp90, and gp96/grp94 elicits a protective immunity to the tumor from which the vaccine was purified (63, 167,175). Methods for purifying HSP individually are now readily available (103,155).

Pilot studies on immunization of cancer patients with HSPs are ongoing (72). Immunization with autologous gp96-elicited MHC I-restricted, tumor- 
specific CD8(+) T lymphocytes and the expansion of the NK cell population was observed in the majority of patients immunized. These observations are entirely consistent with the murine experience and form a firm basis for future trials with clinical end points, using autologous, patient-specific HSPpeptide vaccine (72).

There is now comprehensive experimental evidence that the antigenicity of tumor-derived hsp70, hsp90, and gp96 preparations results from diverse arrays of endogenous peptide antigens complexed with stress proteins $(11,62)$. Vaccination with tumor-derived stress protein/peptide complexes leads to their uptake and processing by professional antigen-presenting cells and to presentation of associated tumor peptide antigens to cytotoxic T cells (173). This induces a tumor-specific CTL response. The attractiveness of the concept of using tumor-derived stress proteins as vaccines is derived from two observa- tions: (i) tumor stress protein vaccines mirror the individual antigenicity of a tumor, which results from random mutations due to genetic instability; and (ii) stress proteins represent powerful adjuvants for the peptide antigens complexed to them (63). DNA vaccination using HSPs as fusion proteins is being considered as a way to greatly enhance the potency of DNA vaccines via the CD8-dependent pathway (34).

The success of bacterial vaccines inducing humoral responses that target carbohydrates on bacteria $(5,25,51,117)$ has spurred interest in developing such vaccines against tumor-associated carbohydrate (TAC) antigens $(90,92)$. Carbohydrate antigen targets have been identified that include the $\mathrm{T} / \mathrm{Tn} / \mathrm{sTn}$ and related carbohydrate antigens such as Lewis Y and Globo H (Figure 1) (84,95, 96,131,152,154), and gangliosides GM2, GD2, and GD3 on melanomas $(90,92)$. Several carbohydrate-conjugate vaccines are in clinical trials, most notably Biomira's THERATOPE sTNKLH (KLH, keyhole limpet hemocyanin) cancer vaccine being tested in high-risk breast and ovarian patients (66). Carbohydrate antigens are perceived to induce only humoral responses; however, cellular responses have been noted with Biomira's THERATOPE in breast and ovarian patients (140).

Novel approaches to vaccine design using gene transfection of tumor cells with cytokines, co-stimulatory molecules, or MHC genes $(28,80,129,177)$ are promising. The development of genetically modified "whole" tumor cell vaccines for cancer therapy relies on the efficient transduction and expression of genes by vectors. Therefore, approaches to develop vectors or optimize gene delivery are being examined $(7,33,102,110,164)$. DNA immunization using TAA $(8,134,157)$ or anti-idiotypic antibodies $(17,157)$, and tumor gene transfection of DC $(44,116,135$,

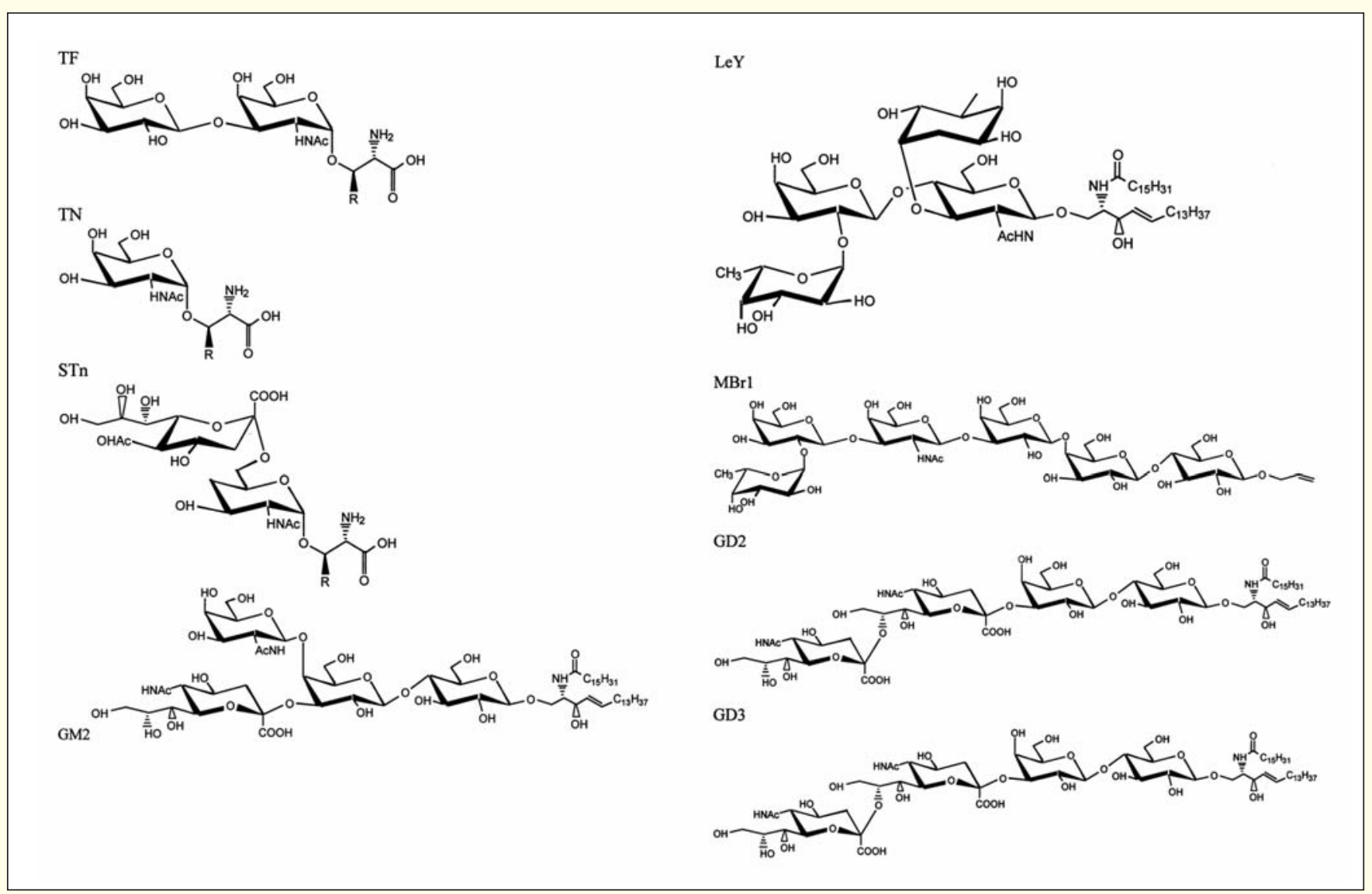

Figure 1. Representative carbohydrate antigens that are being evaluated as carbohydrate-based vaccines for cancer immunotherapy. TN, TF, and LeY have been synthesized as cluster antigens conjugated to KLH for clinical testing (37). GM2 has also been coupled to KLH (32). MBr1 (Globo H) conjugates have shown an ability to induce immune responses in humans (152). 


\section{DRUG DISCOVERY \\ AND GENOMIC TECHNOLOGIES}

$138,161)$ or with idiotypic fragments or peptide (163) are promising.

Concepts associated with cross-priming that focuses on the essential role of CD4+ Th cell-activation for optimal CD8+ T cell-mediated killing of autologous tumors $(12,15,61,114)$ also provide the basis for the design of novel protocols in cellular adoptive immunotherapy of cancer, utilizing synthetic peptides capable of inducing $\mathrm{T}$ cell help in vivo. While CTL are likely to participate prominently in many models of tumor rejection, indirect mechanisms of recognition/rejection have the theoretical advantage of remaining operative even when individual tumor cells evade direct contact by down-regulating MHC and/or antigen expression $(36,120)$.

\section{LIMITATIONS OF IMMUNOTHERAPY}

Antibody- and immune T cell-mediated immune reactions to tumor cells do not always correlate with clinical response. While murine models display promise in vaccine studies, clinical trials in humans have been somewhat disappointing (20). It is becoming generally acknowledged that the use of cancer vaccines, at present, is destined to remain limited to their employment as adjuvant to traditional therapy (23) and in the management of minimal residual disease following surgical resection of the primary cancer mass (20). As therapeutic strategies to prevent development of metastases have potential impact on cancer mortality, development of these therapies requires a better understanding of the biology and molecular events of the metastatic process (31).

Several scenarios have been proposed to be responsible for tumor immune-escape mechanisms (99). There is accumulating evidence for escape mechanisms of tumor cells that include loss of antigen or class I expression, production of suppressive cytokine by tumor cells, and expression of HSP, Fas ligand, and on tumor cells. Considering the fact that escape variants expanded again after nearly complete rejection, it is important to determine how to prevent these tumor escape mechanisms to obtain durable remissions.
The elucidation of the immune deficit against cancer progression has been a difficult task with no single mechanism explaining the complicated cancer-host immune interactions. In the first instance, the failure of cancer vaccines to fulfill their promise might be due to the very relationship between host and tumor-through a natural selection process. The host leads to the selective enrichment of clones of highly aggressive neoplastically transformed cells, which apparently are so dedifferentiated that they no longer express tumor target specific molecules (123). Specific activation of the immune system in such cases only leads to lysis of the remaining cells expressing the particular TAAs in the context of the particular human leukocyte antigen (HLA) subclass and the necessary costimulatory molecules $(6,99)$. The most dangerous clones of tumor cells, however, lack these features, and, thus, the cancer vaccine is of little use.

There is always the possibility of faulty antigen presentation, which could result in tolerance induction to the antigens contained within the vaccine and subsequent rapid tumor progression. Even if an appropriate antigen-specific response is induced, it may not be long lasting because of the absence of poor induction of a memory response (41). It has been noted that effective vaccines need to be given regularly (e.g., monthly) in the presence of even minimal residual disease (41). This may likely be due to tumor antigens being self-antigens. Although it is possible to break tolerance, induction of long lasting memory $\mathrm{T}$ cells may lead to autoimmune responses $(147,176)$.

Awareness of these mechanisms of immune escape will help to direct development of the next generation of tumor vaccines. Targeting unique antigens and modulating the cytokine environment likely will be critical to comprehensive vaccine systems in the future (151). In accordance with the fact that CTL induction is associated with a Th-1 type immune response, it has been shown that CD4+ T cells that can secrete Th1-type cytokines have a beneficial role in protection against tumor development $(68,172)$. The shift from Th1-type to Th2-type cytokine production is found in progressive cancer patients (121), and T cells harvested from tumor-bearing hosts produced only Th2-type cytokines when they were stimulated in vitro (97). In addition to these findings, Th2-type cytokines could even accelerate the experimental pulmonary metastasis of melanoma (82). In more recent studies on immunosurveillance mechanisms, it has been concluded that CD8+ CTL appear to be critical for causing tumor regression, but quantity of CTL alone is not sufficient (100). Rather, qualitatively different CTL that produce more

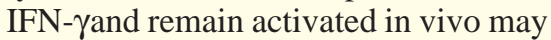
be critical (100). Simply the Th1/Th2 balance cannot explain CD4+ cells that regulate the $\mathrm{CD} 8+$ response. Further studies to determine the mechanism of this regulation will be important for designing optimal immunotherapy. Concurrent abrogation of the inhibitory effects of CD4 cells without eliminating IFN- $\gamma$ production may provide a successful concerted approach to cancer immunotherapy (100).

\section{ROLE OF HUMORAL RESPONSES TO TUMOR ANTIGENS}

Since the first vaccines against infectious diseases were developed, treating cancer with vaccines has been a long sought goal (38). Most bacterial vaccines function through antibodymediated mechanisms. It is clear from past experience that all currently available treatment modalities for cancer are far from perfect (54). Clinical research in antibody-based cancer therapy has been driven for many years by the prospect of identifying cell-surface antigens with sufficiently restrictive tissue expression patterns to allow the specific targeting of antibody to tumor tissue. Few if any such antibodies capable of targeting rapidly and efficiently to solid tumors have been identified (53). Reviews of clinical trials using antibody-based therapy reveal that this approach can, in rare cases, induce complete remission in individual patients with cancer (53). Since these trials have usually involved patients with large tumor masses, tumor cell inacces- 
sibility is probably a major reason for prevailing failures.

Immunoglobulins have evolved to optimally protect an organism from foreign invaders rather than to act as an efficient carrier molecule for therapeutic reagents. Antibodies that mediate cytolysis of disseminated cells are best represented by the colorectal cancer-associated 17-1A antibody, Panorex ${ }^{\mathrm{T}}$ (approved in Germany and heading for approval in the US), which mediates tumor cell destruction through antibody-dependent effector mechanisms $(14,43,83)$. This antibody is actually a murine antibody, bucking the present trend of using humanized antibodies in immunotherapy (55). Rituxan ${ }^{\text {TM}}$ (IDEC Pharmaceuticals), the first cancer-directed antibody (humanized) approved in the US for cancer immunotherapy (B cell malignancies), also appears to mediate cytolysis through a complement mechanism (59) but might also promote apoptosis (146). In contrast, Herceptin ${ }^{\mathrm{T}}$ (Genentech), approved for treating breast cancer, appears to mediate tumor inhibition through down-regulating the HER2 receptor (156). Active immunotherapy against TAAs may be advantageous over passive immunotherapy with MAbs by inducing sustained immunity. Consequently, cancer vaccines that induce primarily humoral responses such as carbohydrate-based vaccines will likely be most effective in the minimal disease setting, the stage when tumor cells are few and dispersed (micrometastases) $(49,126,127,133)$.

\section{Bacterial Model for Antitumor Response}

A role played by antibodies might be viewed in the context of infectious disease systems. While tumor immunity is not the same as immunity for infectious pathogens, there are similarities. Bacterial vaccines presently approved appear to work through antibody responses, with limited evidence for cellular immunity in clearing infection $(5,51,77)$. An important role played by B cells is also recognized in acute and chronic viral and parasitic infection (13). Vaccines against infectious disease do not prevent infection but limit its spread from its point of contact. Consequently, antibodies prevent blood-borne dissem- ination of disease, having limited efficacy against microorganisms in tissue sites. Likewise, cancer vaccines that induce humoral responses may be effective at preventing micrometastases. Cancer patients who have been "surgically cured" (after removal of the primary cancer or positive lymph nodes) are quite similar to patients being re-exposed to infectious disease. The primary targets in both cases are circulating pathogens and the microscopic spread of tumor cells.

\section{Tissue Rejection Model for Antitumor Response}

The best argument for the potential role of antibodies in tissue or tumor rejection comes from the effects of natural antibodies against the gal (1-3) gal antigen found in primates (67). These natural antibodies, arising from exogenous expression of the carbohydrate antigen found on bacteria and food, are not just passive bystanders but are capable of inducing potent and rapid rejection of tissues in transplantation. The irony is that natural antibodies against gal (1-3) gal in primates cause rejection of pig organ xenograft. The concept of inducing autoimmune responses to self-antigens has been the focus of identifying tumor-associated self-antigens recognized by $T$ cells as tumor rejection antigens $(115,118)$. Only such studies have focused on the notion that CTL generation to self-antigens will ultimately reject tissue (tumor). It is apparent that both naturally occurring antibodies and $\mathrm{T}$ cells are present in cancer patients and the role of vaccines is to stimulate (augment or enhance) these respective immune response arms with the hope of causing autoimmune-like responses leading to tissue rejection. Unlike T cells, B cells affinity mature. Consequently, if the idea is to attack cancer, using concepts of tissue rejection, B cells are actually the most likely to target self-antigens.

\section{CARBOHYDRATES AS SELF- ANTIGEN TUMOR TARGETS}

The potential of carbohydrate vaccines in the adjuvant setting (treating minimal residual disease) suggests that emphasis should be placed on further augmenting the immune response against these tumor antigens (178). Carbohydrate antigens are the most prominent antigen types on a tumor cell surface, being expressed at a high density. Carbohydrate antigens are generally weak immunogenic self-antigens, as they are $\mathrm{T}$ cell-independent antigens. Two major approaches are currently being used by various investigators to qualitatively and quantitatively modulate immune responses to carbohydrates. In the first, the carbohydrate itself coupled to carrier and/or mixed with adjuvant is used as the immunogen. In the second, protein or peptide mimetics of carbohydrates are used. Conjugation of carbohydrate to a carrier protein that elicits carrier-specific Tand B-cell responses does not necessarily enhance carbohydrate immunogenicity (101). Carbohydrate-conjugate vaccines that are in the clinic predominately induce humoral responses that are considered beneficial because they mediate complement-dependent cytotoxicity (CDC) or antibody-dependent cytotoxicity (ADCC). IgM antibody production after vaccination better correlates with improved survival than IgG (75). It is the expectation, based on evidence from carbohydrate vaccination trials $(64,75,81,91,93-95,109)$ that antibodies in general and anticarbohydrate antibodies in particular can play a role in vivo in tumor regression, potentially opsonizing tumor cells to prevent extravasation, intravasation, and metastasis. Anticarbohydrate antibodies have shown in animal models that they can mediate targeting micrometastases (178). Antibodies directed toward carbohydrates on $\mathrm{T}$ cells may also be potent T-cell activators (141).

\section{MOLECULAR MIMICRY OF CARBOHYDRATE ANTIGENS}

Some carbohydrate antigens are hard to purify or synthesize despite advances in synthetic approaches. Surrogates or mimics of carbohydrate antigens have been long proposed as possible immunogens to induce carbohydrate cross-reactive immune responses. An anti-idiotypic surrogate for the GD3 ganglioside referred to as Bec2 is being 


\section{DRUG DISCOVERY \\ AND GENOMIC TECHNOLOGIES}

considered in a Phase III clinical trial along with BCG as adjuvant therapy following chemotherapy and irradiation (52). An anti-idiotypic antibody that mimics the GD2 ganglioside is also in clinical trial (46). These antibody-based vaccines may induce both humoral and cellular responses in the form of delaytype hypersensitivity (DTH) activity. Surrogate antigens may overcome unresponsiveness of patients to some carbohydrate antigens since they present their antigenic determinants in a different molecular configuration and therefore may stimulate clones unresponsive to the original antigen (143). Peptides as mimetics of carbohydrate antigens have also been proposed $(4,124,128,130,160$, 166,174,179).

Peptide mimeotopes can induce responses targeting TAC antigens inhibiting tumor growth in vivo in a murine model (78). Peptide mimeotopes can provide immunological memory for TAC antigen (78). As T dependent (TD) antigens, they should prime for longerlasting immune responses to TAC, providing anamnestic or secondary responses related to vaccine composition, form, and delivery. Memory or secondary responses could thwart repeated presentation of metastases by maintaining high levels of circulating antibodies.

Peptide mimeotopes may also augment cellular responses. It is possible that $\mathrm{T}$ cells can react with glycopeptides. It has been shown that $\mathrm{T}$ cells can specifically recognize synthetic glycopeptides $(1,48,60,73,74,105)$. However, whether glycopeptides are selected for presentation through antigen processing mechanisms to eventually elicit carbohydrate-specific T cells is still an open question. Peptide mimeotopes of carbohydrate antigens have been shown to elicit cross-reactive CTLs to the MUC1 protein $(9,10)$. However, this mimicry is more based on similarities between the peptides as opposed to $\mathrm{T}$ cells recognizing carbohydrate structures. Nevertheless, this observation speaks to the complexity that remains in vaccine design.

Peptide mimeotopes of carbohydrate antigens have a further advantage in that DNA vaccine strategies can be implemented to augment carbohydratereactive immune responses (79) much like using TAA or anti-idiotypic antibody encoding plasmids. DNA vaccines provide a strategy to effectively induce cellular responses to TAA including Th1-associated responses that are critical in cancer vaccine efficacy $(136,144)$. Peptide mimetics of carbohydrate antigens encoded into DNA plasmids provide an opportunity to induce a cross-reactive Th1 response to carbohydrate antigen upon mimeotope immunization (79). In recent studies, the feasibility of inducing cross-reactive responses to TAC using DNA encoding peptide mimeotopes of carbohydrate antigens was confirmed (79). DNA immunization induced a predominant IgG2a response to the synthetic TAC antigen LeY (Figure 2). Most importantly, we observed that immunization with mimeotope-encoding DNA primed for a LeY boost (Figure 3). Induced IgM after carbohydrate boost was transient and dropped quickly. We also examined the functionality of induced antiserum using a complementdependent cytotoxic model targeting the LeY expressing human MCF7 breast tumor cell line. As shown in Table 2, the induced cytotoxicity of the sera was increased after boosting with nominal carbohydrate. Our results suggest that DNA immunization with encoded mimeotopes can be part of prime-boost strategies to improve the response to carbohydrate antigens. However, strategies to enhance the titers must be further evaluated. The encoding of peptide mimeotopes into DNA cassettes that also include identified MHC class I epitopes that induce CTLs that target tumor expressed TAA should further define a novel strategy for future vaccine development.

Another viable strategy using peptide mimeotopes may lie in the idea that peptides can associate with the CD1 molecule expressed on DC (29). CD1 molecules comprise a novel lineage of antigen-presenting molecules, distinct from MHC class I and II molecules. Unlike MHC molecules, the CD1 molecules appear to accommodate lipid, glycolipid, and peptide antigens in their hydrophobic cavity for presentation to a wide variety of $\mathrm{T}$ cells

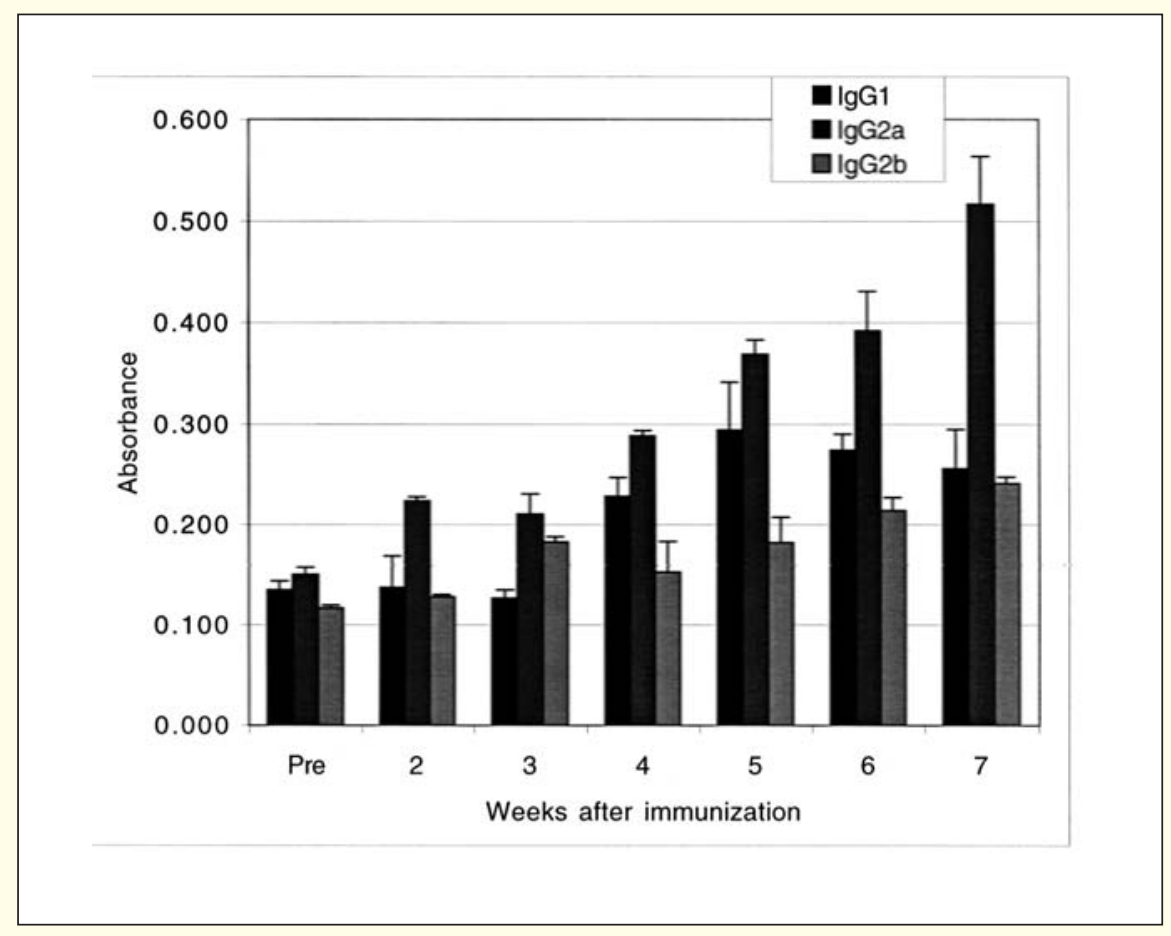

Figure 2. Kinetic isotyping of antibody responses in pcDNAggi [PcDNAggi plasmid was generated to express a mimeotope and a T-helper epitope (79)] immunized mice. Representative sera from one experimental group of mice $(n=4)$ were collected and pooled from week 2 to week 7 after immunization. Pooled sera were diluted 1:50, and serum binding to LeY was assessed by anti-IgG1, IgG2a, and IgG2b antibodies. Standard deviation bars were calculated based on triplicate samples. The experiment was repeated twice more with similar results. 
Table 2. CDC Assay with Human MCF7 Cells Using Sera Collected Before Carbohydrate Boost and Two Weeks After That

\begin{tabular}{|lcc|}
\hline \multicolumn{2}{|c|}{ CDC (\%) } \\
\cline { 2 - 3 } Immunization & Before Boost & After Boost \\
\hline Naive & 9.93 & 7.45 \\
Vector & 8.69 & 8.69 \\
pcDNAggi & $13.66^{\mathrm{a}}$ & $19.67^{\mathrm{b}}$ \\
aStatistically significant compared with vector immunized animals at $P<0.01$, \\
using Student's $t$ test. & & \\
bStatistically significant compared with pcDNAggi immunized animals before \\
boost at $P<0.025$, using Student's $t$ test. PcDNAggi is explained in legend to \\
Figure 2.
\end{tabular}

(158). CD1a+ cells are closely associated with tumor cells (65). The presence of a high number of infiltrating CD1a+ cells in malignant neoplasms has been reported to be associated with an improved prognosis, reduced tumor recurrence, and fewer metastases. It is likely that CD1a+ cells have a role in antigen capture and presentation in human tumors. Immunizing with loading DC with peptide mimetics of carbohydrate antigens may lend to localized responses to carbohydrates as DC infiltrate into select tumors such as breast tumors.

\section{CONCLUSION}

Recent progress in defining the immunogenic epitopes of tumor antigens and in augmenting their immunogenicity, along with new information on the

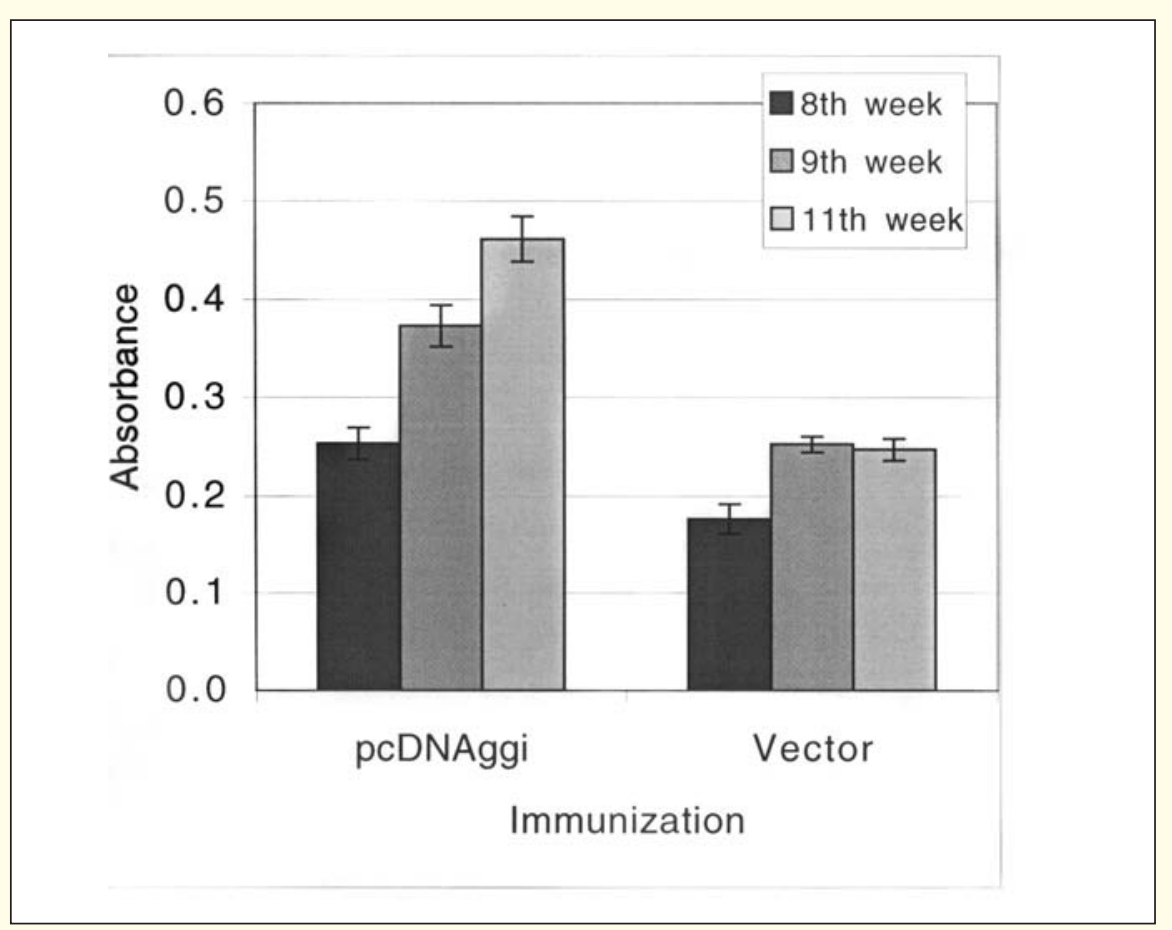

Figure 3. Serum reactivity with LeY in DNA immunized mice before and after LeY boost. Immunized mice were bled and boosted with carbohydrate (8th week) and then bled again one (9th week) and three weeks (11th week) after boost. Collected sera from pooled blood were diluted 1:50 and studied for binding to LeY by ELISA using goat anti-mouse IgG as secondary antibody. PcDNAggi is explained in legend to Figure 2. mechanisms of tumor antigen presentation, has rejuvenated the field of cancer vaccines. A variety of strategies have been developed in which human tumor antigens, when presented appropriately with co-stimulatory molecules and/or with cytokines, can break the host's natural tolerance toward its tumor and induce rejection strength immune reactions, even in patients with metastatic disease. The identification and availability of tumor-associated antigens now allows the possibility of eliciting humoral (antibody-mediated) and cellmediated immunity to be tested, which may result in direct or indirect tumor destruction. As cell-mediated immunity is considered important in cancer vaccine efforts, the identification of both MHC class I and II restricted tumor antigens provides new opportunities for the development of therapeutic strategies against cancer. Based on historical vaccine concepts, the relative importance of antibody responses to tumor antigens is also being reconsidered. TAC-based vaccines induce primarily humoral responses to tumor cells much as they do in bacterial applications. This reconsideration also provides new opportunities. The interconversion of TAC antigens into peptide forms has the potential to further manipulate immune responses to target these antigen types. Ultimately, for successful active specific immunization against human cancers, an understanding of the immunoevasive maneuvers of the tumor cell is still essential.

\section{ACKNOWLEDGMENT}

This work was supported by National Institutes of Health grant no. R01 AI45133 to T.K.E.

\section{REFERENCES}

1.Abdel-Motal, U., L. Berg, A. Rosen, M. Bengtsson, C.J. Thorpe, J. Kihlberg, J. Dahmen, G. Magnusson, K.A. Karlsson, and M. Jondal. 1996. Immunization with glycosylated Kb-binding peptides generates carbohydrate-specific, unrestricted cytotoxic T cells. Eur. J. Immunol. 26:544-551.

2.Ada, G. 1999. The coming of age of tumour immunotherapy. Immunol. Cell Biol. 77:180185.

3.Adluri, S., F. Helling, S. Ogata, S. Zhang, 
S.H. Itzkowitz, K.O. Lloyd, and P.O. Livingston. 1995. Immunogenicity of synthetic TF-KLH (keyhole limpet hemocyanin) and sTn-KLH conjugates in colorectal carcinoma patients. Cancer Immunol. Immunother. 41:185-192.

4.Agadjanyan, M., P. Luo, M.A. Westerink, L.A. Carey, W. Hutchins, Z. Steplewski, D.B. Weiner, and T. Kieber-Emmons. 1997. Peptide mimicry of carbohydrate epitopes on human immunodeficiency virus. Nat. Biotechnol. 15:547-551.

5.Ahmad, H. and E.K. Chapnick. 1999. Conjugated polysaccharide vaccines. Infect. Dis. Clin. North Am. 13:113-133.

6.Algarra, I., T. Cabrera, and F. Garrido. 2000. The HLA crossroad in tumor immunology. Hum. Immunol. 61:65-73.

7.Ali, S.A., C.S. McLean, M.E. Boursnell, G. Martin, C.L. Holmes, S. Reeder, C. Entwisle, D.M. Blakeley et al. 2000. Preclinical evaluation of "whole" cell vaccines for prophylaxis and therapy using a disabled infectious single cycle-herpes simplex virus vector to transduce cytokine genes. Cancer Res. 60:1663-1670.

8.Amici, A., A. Smorlesi, G. Noce, G. Santoni, P. Cappelletti, L. Capparuccia, R. Coppari, R. Lucciarini, C. Petrelli, and M. Provinciali. 2000. DNA vaccination with full-length or truncated neu induces protective immunity against the development of spontaneous mammary tumors in HER-2/neu transgenic mice. Gene Ther. 7:703-706.

9.Apostolopoulos, V., M.S. Sandrin, and I.F. McKenzie. 1999. Carbohydrate/peptide mimics: effect on MUC1 cancer immunotherapy. J. Mol. Med. 77:427-436.

10.Apostolopoulos, V., M.S. Sandrin, and I.F. McKenzie. 1999. Mimics and cross reactions of relevance to tumour immunotherapy. Vaccine 18:268-275.

11.Argon, Y. and B.B. Simen. 1999. GRP94, an ER chaperone with protein and peptide binding properties. Semin. Cell. Dev. Biol. 10:495-505.

12.Armstrong, T.D., B.A. Pulaski, and S. Ostrand-Rosenberg. 1998. Tumor antigen presentation: changing the rules. Cancer Immunol. Immunother. 46:70-74.

13.Bachmann, M.F. and M. Kopf. 1999. The role of $\mathrm{B}$ cells in acute and chronic infections. Curr. Opin. Immunol. 11:332-329.

14.Balzar, M., M.J. Winter, C.J. de Boer, and S.V. Litvinov. 1999. The biology of the 17-1A antigen (Ep-CAM). J. Mol. Med. 77:699-712.

15.Baxevanis, C.N., I.F. Voutsas, O.E. Tsitsilonis, A.D. Gritzapis, R. Sotiriadou, and $M$. Papamichail. 2000. Tumor-specific CD4+ T lymphocytes from cancer patients are required for optimal induction of cytotoxic $\mathrm{T}$ cells against the autologous tumor. J. Immunol. 164:3902-3912.

16.Ben-Hur, H., A. Ben-Meir, Z. Hagay, V. Berman, B. Schwartsburd, P. Gurevich, B. Sandler, Y. Tendler, O. Zinder, and I. Zusman. 1998. Tumor-preventive effects of the soluble p53 antigen on chemically-induced skin cancer in mice. Anticancer Res. 18:4237-4241.

17.Benvenuti, F., O.R. Burrone, and D.G. Efremov. 2000. Anti-idiotypic DNA vaccines for lymphoma immunotherapy require the pres- ence of both variable region genes for tumor protection. Gene Ther. 7:605-611.

18.Berthier-Vergnes, O., J. Portoukalian, E. Leftheriotis, and J.F. Dore. 1994. Induction of IgG antibodies directed to a M(r) 31,000 melanoma antigen in patients immunized with vaccinia virus melanoma oncolysates. Cancer Res. 54:2433-2439.

19.Bhattachary-Chatterjee, M., R. Nath Baral, S.K. Chatterjee, R. Das, H. Zeytin, M. Chakraborty, and K.A. Foon. 2000. Counterpoint. Cancer vaccines: single-epitope antiidiotype vaccine versus multiple-epitope antigen vaccine. Cancer Immunol. Immunother. 49:133-141.

20.Bodey, B., B. Bodey, Jr., S.E. Siegel, and H.E. Kaiser. 2000. Failure of cancer vaccines: the significant limitations of this approach to immunotherapy. Anticancer Res. 20:2665-2676.

21.Boon, T., P.G. Coulie, and B. Van den Eynde. 1997. Tumor antigens recognized by $\mathrm{T}$ cells. Immunol. Today 18:267-268.

22.Boucher, M.J., J. Morisset, P.H. Vachon, J.C. Reed, J. Laine, and N. Rivard. 2000. MEK/ERK signaling pathway regulates the expression of Bcl-2, Bcl-X(L), and Mcl-1 and promotes survival of human pancreatic cancer cells. J. Cell. Biochem. 79:355-369.

23.Bremers, A.J., P.J. Kuppen, and G. Parmiani. 2000. Tumour immunotherapy: the adjuvant treatment of the 21st century? Eur. J. Surg. Oncol. 26:418-424.

24.Bremers, A.J. and G. Parmiani. 2000. Immunology and immunotherapy of human cancer: present concepts and clinical developments. Crit. Rev. Oncol. Hematol. 34:1-25.

25.Breukels, M.A., G.T. Rijkers, M.M. Voorhorst-Ogink, B.J. Zegers, and L.A. Sanders. 1999. Pneumococcal conjugate vaccine primes for polysaccharide-inducible IgG2 antibody response in children with recurrent otitis media acuta. J. Infect. Dis. 179:1152-1156.

26.Brinckerhoff, L.H., L.W. Thompson, and C.L. Slingluff, Jr. 2000. Melanoma vaccines. Curr. Opin. Oncol. 12:163-173.

27.Bronte, V., E. Apolloni, R. Ronca, P. Zamboni, W.W. Overwijk, D.R. Surman, N.P. Restifo, and P. Zanovello. 2000. Genetic vaccination with "self" tyrosinase-related protein 2 causes melanoma eradication but not vitiligo. Cancer Res. 60:253-258.

28.Callahan, G.N. and D.R. Leach. 1996. Tumor cells engineered to express major histocompatibility complex class II molecules induce T helper cell-dependent responses that protect mice from normally lethal doses of unmodified tumor cells. Cancer Detect. Prev. 20:199-206.

29.Castano, A.R., S. Tangri, J.E. Miller, H.R. Holcombe, M.R. Jackson, W.D. Huse, M. Kronenberg, and P.A. Peterson. 1995. Peptide binding and presentation by mouse CD1. Science 269:223-226.

30.Cerundolo, V. 1999. T cells work together to fight cancer. Curr. Biol. 9:R695-R697.

31.Chambers, A.F., I.C. MacDonald, E.E. Schmidt, V.L. Morris, and A.C. Groom. 2000. Clinical targets for anti-metastasis therapy. Adv. Cancer Res. 79:91-121.

32.Chapman, P.B., D.M. Morrissey, K.S.
Panageas, W.B. Hamilton, C. Zhan, A.N. Destro, L. Williams, R.J. Israel, and P.O. Livingston. 2000. Induction of antibodies against GM2 ganglioside by immunizing melanoma patients using GM2-keyhole limpet hemocyanin + QS21 vaccine: a doseresponse study. Clin. Cancer Res. 6:874-879.

33.Chatterjee, S.K., H. Qin, S. Manna, and P.K. Tripathi. 1999. Recombinant vaccinia virus expressing cytokine GM-CSF as tumor vaccine. Anticancer Res. 19:2869-2873.

34.Chen, C.H., T.L. Wang, C.F. Hung, Y. Yang, R.A. Young, D.M. Pardoll, and T.C. Wu. 2000. Enhancement of DNA vaccine potency by linkage of antigen gene to an HSP70 gene. Cancer Res. 60:1035-1042.

35.Chen, J.L., P.R. Dunbar, U. Gileadi, E. Jager, S. Gnjatic, Y. Nagata, E. Stockert, D.L. Panicali, Y.T. Chen, A. Knuth, L.J. Old, and V. Cerundolo. 2000. Identification of NY-ESO-1 peptide analogues capable of improved stimulation of tumor-reactive CTL. J. Immunol. 165:948-955.

36.Cohen, P.A., L. Peng, G.E. Plautz, J.A. Kim, D.E. Weng, and S. Shu. 2000. CD4+ T cells in adoptive immunotherapy and the indirect mechanism of tumor rejection. Crit. Rev. Immunol. 20:17-56.

37.Danishefsky, S.J. and J.R. Allen. 2000. From the laboratory to the clinic: a retrospective on fully synthetic carbohydrate-based anticancer vaccines. Angew Chem. Int. Ed. Engl. 39:836-863.

38.Del Vecchio, M. and G. Parmiani. 1999. Cancer vaccination. Forum (Genova) 9:239256.

39.Dillman, R.O., S.K. Nayak, N.M. Barth, C. DeLeon, L.S. Schwartzberg, L.E. Spitler, C. Church, A.A. O'Connor, and L.D. Beutel. 1998. Clinical experience with autologous tumor cell lines for patient-specific vaccine therapy in metastatic melanoma. Cancer Biother. Radiopharm. 13:165-176.

40.Dranoff, G. 1999. Interpreting cancer vaccine clinical trials. J. Gene Med. 1:80-83.

41.Durrant, L.G., D.J. Buckley, R.A. Robins, and I. Spendlove. 2000. 105Ad7 cancer vaccine stimulates anti-tumour helper and cytotoxic T-cell responses in colorectal cancer patients but repeated immunisations are required to maintain these responses. Int. J. Cancer 85:87-92.

42.Eton, O., D.D. Kharkevitch, M.A. Gianan, M.I. Ross, K. Itoh, M.W. Pride, C. Donawho, A.C. Buzaid et al. 1998. Active immunotherapy with ultraviolet B-irradiated autologous whole melanoma cells plus DETOX in patients with metastatic melanoma. Clin. Cancer Res. 4:619-627.

43.Flieger, D., U. Spengler, I. Beier, T. Sauerbruch, and I. Schmidt-Wolf. 2000. Combinations of the cytokines Il-12, Il-2 and Ifn-alpha significantly augment whereas the cytokine Il-4 suppresses the cytokine-induced antibody-dependent cellular cytotoxicity of monoclonal antibodies 17-1a and BR55-2. Cytokine 12:756-761.

44.Fong, L. and E.G. Engleman. 2000. Dendritic cells in cancer immunotherapy. Annu. Rev. Immunol. 18:245-273.

45.Foon, K.A., W.J. John, M. Chakraborty, R. Das, A. Teitelbaum, J. Garrison, O. Kasha- 
la, S.K. Chatterjee, and M. BhattacharyaChatterjee. 1999. Clinical and immune responses in resected colon cancer patients treated with anti-idiotype monoclonal antibody vaccine that mimics the carcinoembryonic antigen. J. Clin. Oncol. 17:2889-2895.

46.Foon, K.A., J. Lutzky, R.N. Baral, J.R. Yannelli, L. Hutchins, A. Teitelbaum, O.L. Kashala, R. Das, J. Garrison, R.A. Reisfeld, and M. Bhattacharya-Chatterjee. 2000. Clinical and immune responses in advanced melanoma patients immunized with an antiidiotype antibody mimicking disialoganglioside GD2. J. Clin. Oncol. 18:376-384.

47.Freedman, R.S., C.L. Edwards, J.M. Bowen, E. Lotzova, R. Katz, E. Lewis, N. Atkinson, and R. Carsetti. 1988. Viral oncolysates in patients with advanced ovarian cancer. Gynecol. Oncol. 29:337-347.

48.Galli-Stampino, L., E. Meinjohanns, K. Frische, M. Meldal, T. Jensen, O. Werdelin, and S. Mouritsen. 1997. T-cell recognition of tumor-associated carbohydrates: the nature of the glycan moiety plays a decisive role in determining glycopeptide immunogenicity. Cancer Res. 57:3214-3222.

49.Garrett, T.J., L.T. Vahdat, and D.W. Kinne. 1997. Systemic adjuvant therapy of breast cancer. J. Surg. Oncol. 64:167-172.

50.Gibbons, N.B., R.W. Watson, R.N. Coffey, H.P. Brady, and J.M. Fitzpatrick. 2000. Heat-shock proteins inhibit induction of prostate cancer cell apoptosis. Prostate 45:58-65.

51.Goldblatt, D. 1998. Recent developments in bacterial conjugate vaccines. J. Med. Microbiol. 47:563-567.

52.Grant, S.C., M.G. Kris, A.N. Houghton, and P.B. Chapman. 1999. Long survival of patients with small cell lung cancer after adjuvant treatment with the anti-idiotypic antibody BEC2 plus Bacillus Calmette-Guerin. Clin. Cancer Res. 5:1319-1323.

53.Green, M.C., J.L. Murray, and G.N. Hortobagyi. 2000. Monoclonal antibody therapy for solid tumors. Cancer Treat. Rev. 26:269-286.

54.Greten, T.F. and E.M. Jaffee. 1999. Cancer vaccines. J. Clin. Oncol. 17:1047-1060.

55.Gruber, R., L.J. van Haarlem, S.O. Warnaar, E. Holz, and G. Riethmuller. 2000. The human antimouse immunoglobulin response and the anti-idiotypic network have no influence on clinical outcome in patients with minimal residual colorectal cancer treated with monoclonal antibody CO17-1A. Cancer Res. 60:1921-1926.

56.Hadden, J.W. 1999. The immunology and immunotherapy of breast cancer: an update. Int. J. Immunopharmacol. 21:79-101.

57.Haigh, P.I., L.A. Difronzo, G. Gammon, and D.L. Morton. 1999. Vaccine therapy for patients with melanoma. Oncology (Huntingt) 13:1561-1574.

58.Hampton, T.A., R.M. Conry, M.B. Khazaeli, D.R. Shaw, D.T. Curiel, A.F. LoBuglio, and T.V. Strong. 2000. SEREX analysis for tumor antigen identification in a mouse model of adenocarcinoma. Cancer Gene Ther. 7:446455.

59.Harjunpaa, A., S. Junnikkala, and S. Meri. 2000. Rituximab (anti-CD20) therapy of Bcell lymphomas: direct complement killing is superior to cellular effector mechanisms.
Scand. J. Immunol. 51:634-641.

60.Haurum, J.S., L. Tan, G. Arsequell, P. Frodsham, A.C. Lellouch, P.A. Moss, R.A. Dwek, A.J. McMichael, and T. Elliott. 1995. Peptide anchor residue glycosylation: effect on class I major histocompatibility complex binding and cytotoxic T lymphocyte recognition. Eur. J. Immunol. 25:3270-3276.

61.Heath, W.R. and F.R. Carbone. 1999. Cytotoxic T lymphocyte activation by cross-priming. Curr. Opin. Immunol. 11:314-318.

62.Heike, M., B. Noll, and K.H. Meyer zum Buschenfelde. 1996. Heat shock protein-peptide complexes for use in vaccines. J. Leukoc. Biol. 60:153-158.

63.Heike, M., A. Weinmann, K. Bethke, and P.R. Galle. 1999. Stress protein/peptide complexes derived from autologous tumor tissue as tumor vaccines. Biochem. Pharmacol. 58:1381-1387.

64.Helling, F., S. Zhang, A. Shang, S. Adluri, M. Calves, R. Koganty, B.M. Longenecker, T.J. Yao, H.F. Oettgen, and P.O. Livingston. 1995. GM2-KLH conjugate vaccine: increased immunogenicity in melanoma patients after administration with immunological adjuvant QS21. Cancer Res. 55:2783-2788.

65.Hillenbrand, E.E., A.M. Neville, and B.J. Coventry. 1999. Immunohistochemical localization of CD1a-positive putative dendritic cells in human breast tumours. Br. J. Cancer. 79:940-944.

66.Holmberg, L.A., D.V. Oparin, T. Gooley, K. Lilleby, W. Bensinger, M.A. Reddish, G.D. MacLean, B.M. Longenecker, and B.M. Sandmaier. 2000. Clinical outcome of breast and ovarian cancer patients treated with

high-dose chemotherapy, autologous stem cell rescue and THERATOPE(R) STn-KLH cancer vaccine. Bone Marrow Transplant. 25:1233-1241.

67.Houghton, A.N. and K.O. Lloyd. 1998. Stuck in the MUC on the long and winding road. Nat. Med. 4:270-271.

68.Hu, H.M., W.J. Urba, and B.A. Fox. 1998. Gene-modified tumor vaccine with therapeutic potential shifts tumor-specific $T$ cell response from a type 2 to a type 1 cytokine profile. J. Immunol. 161:3033-3041.

69.Hwang, I.R., D.H. Nahm, S.N. Cho, B.M. Longenecker, R. Rao Koganty, and I.S. Park. 1999. Anti-T antibodies and peanut-agglutinin-binding glycoproteins in sera of patients with gastric cancer. J. Cancer Res. Clin. Oncol. 125:582-587.

70.Ioannides, C.G., C.D. Platsoucas, J.M. Bowen, J.T. Wharton, and R.S. Freedman. 1989. Increased ovarian tumor cell surface reacting antibodies in patients with ovarian adenocarcinoma after viral oncolysate treatment. Anticancer Res. 9:81-86.

71.Jager, E., D. Jager, and A. Knuth. 1999 CTL-defined cancer vaccines: perspectives for active immunotherapeutic interventions in minimal residual disease. Cancer Metastasis Rev. 18:143-150.

72.Janetzki, S., D. Palla, V. Rosenhauer, H. Lochs, J.J. Lewis, and P.K. Srivastava. 2000. Immunization of cancer patients with autologous cancer-derived heat shock protein gp96 preparations: A pilot study. Int. J. Cancer 88:232-238.
73.Jensen, T., S.L. Galli, S. Mouritsen, K. Frische, S. Peters, M. Meldal, and $\mathbf{O}$. Werdelin. 1996. T cell recognition of Tn-glycosylated peptide antigens. Eur. J. Immunol. 26:1342-1349.

74.Jensen, T., P. Hansen, S.L. Galli, S. Mouritsen, K. Frische, E. Meinjohanns, M. Meldal, and O. Werdelin. 1997. Carbohydrate and peptide specificity of MHC class II-restricted $\mathrm{T}$ cell hybridomas raised against an $\mathrm{O}-$ glycosylated self peptide. J. Immunol. 158: 3769-3778.

75.Jones, R.C., M. Kelley, R.K. Gupta, J.A. Nizze, R. Yee, Z. Leopoldo, K. Qi, S. Stern, and D.L. Morton. 1996. Immune response to polyvalent melanoma cell vaccine in AJCC stage III melanoma: an immunologic survival model. Ann. Surg. Oncol. 3:437-445.

76.Katsura, F., M. Eura, K. Chikamatsu, M. Oiso, E. Yumoto, and T. Ishikawa. 2000. Analysis of individual specific cytotoxic $\mathrm{T}$ lymphocytes for two MAGE-3-derived epitopes presented by HLA-A24. Jpn. J. Clin. Oncol. 30:117-121.

77.Kayhty, H. and J. Eskola. 1996. New vaccines for the prevention of pneumococcal infections. Emerg. Infect. Dis. 2:289-298.

78.Kieber-Emmons, T., P. Luo, J.-P. Qiu, T.Y. Chang, I.O., M. Blaszczyk-Thurin, and Z. Steplewski. 1999. Vaccination with carbohydrate peptide mimotopes promotes anti-tumor responses. Nat. Biotechnol. 17:660-665.

79.Kieber-Emmons, T., B. Monzavi-Karbassi, B. Wang, P. Luo, and D.B. Weiner. 2000. Cutting edge: DNA immunization with minigenes of carbohydrate mimotopes induce functional anti-carbohydrate antibody response. J. Immunol. 165:623-627.

80.Kirk, C.J. and J.J. Mule. 2000. Gene-modified dendritic cells for use in tumor vaccines. Hum. Gene Ther. 11:797-806.

81.Kitamura, K., P.O. Livingston, S.R. Fortunato, E. Stockert, F. Helling, G. Ritter, H.F. Oettgen, and L.J. Old. 1995. Serological response patterns of melanoma patients immunized with a GM2 ganglioside conjugate vaccine. Proc. Natl. Acad. Sci. USA 92:28052809.

82.Kobayashi, M., H. Kobayashi, R.B. Pollard, and F. Suzuki. 1998. A pathogenic role of Th2 cells and their cytokine products on the pulmonary metastasis of murine B16 melanoma. J. Immunol. 160:5869-5873.

83.Kubuschok, B., B. Passlick, J.R. Izbicki, O. Thetter, and K. Pantel. 1999. Disseminated tumor cells in lymph nodes as a determinant for survival in surgically resected non-smallcell lung cancer. J. Clin. Oncol. 17:19-24.

84.Kudryashov, V., H.M. Kim, G. Ragupathi, S.J. Danishefsky, P.O. Livingston, and K.O. Lloyd. 1998. Immunogenicity of synthetic conjugates of Lewis(y) oligosaccharide with proteins in mice: towards the design of anticancer vaccines. Cancer Immunol. Immunother. 45:281-286.

85.Kugler, A., G. Stuhler, P. Walden, G. Zoller, A. Zobywalski, P. Brossart, U. Trefzer, S. Ullrich et al. 2000. Regression of human metastatic renal cell carcinoma after vaccination with tumor cell-dendritic cell hybrids. Nat. Med. 6:332-336.

86.Lamm, D.L. 2000. Preventing progression 
and improving survival with BCG maintenance. Eur. Urol. 37(Suppl 1):9-15.

87.Lee, S., H. Li, T.V. Strong, S.E. Moore, and R.M. Conry. 2000. Development of a polynucleotide vaccine from melanoma antigen recognized by T cells- 1 and recombinant protein from melanoma antigen recognized by $\mathrm{T}$ cells-1 for melanoma vaccine clinical trials. J. Immunother. 23:379-386.

88.Lillehei, K.O., Y. Liu, and Q. Kong. 1999. Current perspectives in immunotherapy. Ann. Thorac. Surg. 68(3 Suppl):S28-S33.

89.Linette, G.P., S. Shankara, S. Longerich, S. Yang, R. Doll, C. Nicolette, F.I. Preffer, B.L. Roberts, and F.G. Haluska. 2000. In vitro priming with adenovirus/gp100 antigen-transduced dendritic cells reveals the epitope specificity of HLA-A*0201-restricted CD8+ T cells in patients with melanoma. J. Immunol. 164:3402-3412.

90.Livingston, P.O. and G. Ragupathi. 1997. Carbohydrate vaccines that induce antibodies against cancer. 2. Previous experience and future plans. Cancer Immunol. Immunother. 45: 10-19.

91.Livingston, P.O., G.Y. Wong, S. Adluri, Y. Tao, M. Padavan, R. Parente, C. Hanlon, M.J. Calves, F. Helling, G. Ritter et al. 1994. Improved survival in stage III melanoma patients with GM2 antibodies: a randomized trial of adjuvant vaccination with GM2 ganglioside. J. Clin. Oncol. 12:1036-1044.

92.Livingston, P.O., S. Zhang, and K.O. Lloyd. 1997. Carbohydrate vaccines that induce antibodies against cancer. 1. Rationale. Cancer Immunol. Immunother. 45:1-9.

93.Longenecker, B.M., M. Reddish, R. Koganty, and G.D. MacLean. 1993. Immune responses of mice and human breast cancer patients following immunization with synthetic sialyl-Tn conjugated to KLH plus detox adjuvant. Ann. NY Acad. Sci. 690:276-291.

94.Longenecker, B.M., M. Reddish, R. Koganty, and G.D. MacLean. 1994. Specificity of the IgG response in mice and human breast cancer patients following immunization against synthetic sialyl-Tn, an epitope with possible functional significance in metastasis. Adv. Exp. Med. Biol. 353:105-124.

95.MacLean, G.D., M. Reddish, R.R. Koganty, T. Wong, S. Gandhi, M. Smolenski, J. Samuel, J.M. Nabholtz, and B.M. Longenecker. 1993. Immunization of breast cancer patients using a synthetic sialyl-Tn glycoconjugate plus Detox adjuvant. Cancer Immunol. Immunother. 36:215-222.

96.MacLean, G.D., M.A. Reddish, R.R. Koganty, and B.M. Longenecker. 1996. Antibodies against mucin-associated sialyl-Tn epitopes correlate with survival of metastatic adenocarcinoma patients undergoing active specific immunotherapy with synthetic STn vaccine. J. Immunother. Emphasis Tumor Immunol. 19:59-68.

97.Maeda, H. and A. Shiraishi. 1996. TGF-beta contributes to the shift toward Th2-type responses through direct and IL-10-mediated pathways in tumor-bearing mice. J. Immunol. 156:73-78.

98.Malmstrom, P. 2000. Improved patient outcomes with BCG immunotherapy vs. chemotherapy-Swedish and worldwide ex- perience. Eur. Urol. 37(Suppl 1):16-20.

99.Marincola, F.M., E.M. Jaffee, D.J. Hicklin, and S. Ferrone. 2000. Escape of human solid tumors from T-cell recognition: molecular mechanisms and functional significance. Adv. Immunol. 74:181-273.

100.Matsui, S., J.D. Ahlers, A.O. Vortmeyer, M. Terabe, T. Tsukui, D.P. Carbone, L.A Liotta, and J.A. Berzofsky. 1999. A model for CD8+ CTL tumor immunosurveillance and regulation of tumor escape by CD4 T cells through an effect on quality of CTL. J. Immunol. 163:184-193.

101.McCool, T.L., C.V. Harding, N.S. Greenspan, and J.R. Schreiber. 1999. B- and T-cell immune responses to pneumococcal conjugate vaccines: divergence between carrierand polysaccharide-specific immunogenicity. Infect. Immun. 67:4862-4869.

102.McLaughlin, J.P., S. Abrams, J. Kantor, M.J. Dobrzanski, J. Greenbaum, J. Schlom, and J.W. Greiner. 1997. Immunization with a syngeneic tumor infected with recombinant vaccinia virus expressing granulocyte-macrophage colony-stimulating factor (GM-CSF) induces tumor regression and long-lasting systemic immunity. J. Immunother. 20:449-459.

103.Menoret, A. and G. Bell. 2000. Purification of multiple heat shock proteins from a single tumor sample. J. Immunol. Methods 237:119130.

104.Menoret, A. and R. Chandawarkar. 1998. Heat-shock protein-based anticancer immunotherapy: an idea whose time has come. Semin. Oncol. 25:654-660.

105.Michaelsson, E., J. Broddefalk, A. Engstrom, J. Kihlberg, and R. Holmdahl. 1996. Antigen processing and presentation of a naturally glycosylated protein elicits major histocompatibility complex class II-restricted, carbohydrate-specific T cells. Eur. J. Immunol. 26:1906-1910.

106.Miles, D.W., K.E. Towlson, R. Graham, M. Reddish, B.M. Longenecker, J. TaylorPapadimitriou, and R.D. Rubens. 1996. A randomised phase II study of sialyl-Tn and DETOX-B adjuvant with or without cyclophosphamide pretreatment for the active specific immunotherapy of breast cancer. $\mathrm{Br}$. J. Cancer. 74:1292-1296.

107.Mitchell, M.S., W. Harel, J. Kan-Mitchell, L.G. LeMay, P. Goedegebuure, X.Q. Huang, F. Hofman, and S. Groshen. 1993. Active specific immunotherapy of melanoma with allogeneic cell lysates. Rationale, results, and possible mechanisms of action. Ann. NY Acad. Sci. 690:153-66.

108.Morton, D.L., L.J. Foshag, D.S. Hoon, J.A. Nizze, E. Famatiga, L.A. Wanek, C. Chang, D.G. Davtyan, R.K. Gupta, R. Elashoff et al. 1992. Prolongation of survival in metastatic melanoma after active specific immunotherapy with a new polyvalent melanoma vaccine. Ann. Surg. 216:463-482.

109.Morton, D.L., M.H. Ravindranath, and R.F. Irie. 1994. Tumor gangliosides as targets for active specific immunotherapy of melanoma in man. Prog. Brain Res. 101:251-275.

110.Nagai, E., T. Ogawa, T. Kielian, A. Ikubo, and T. Suzuki. 1998. Irradiated tumor cells adenovirally engineered to secrete granulocyte/macrophage-colony-stimulating factor establish antitumor immunity and eliminate pre-existing tumors in syngeneic mice. Cancer Immunol. Immunother. 47:72-80.

111.Nair, S.K., D. Snyder, B.T. Rouse, and E. Gilboa. 1997. Regression of tumors in mice vaccinated with professional antigen-presenting cells pulsed with tumor extracts. Int. J. Cancer 70:706-715.

112.Nestle, F.O., G. Burg, and R. Dummer. 1999. New perspectives on immunobiology and immunotherapy of melanoma. Immunol. Today 20:5-7.

113.Onda, T., D. LaFace, G. Baier, T. Brunner, N. Honma, T. Mikayama, A. Altman, and D.R. Green. 1995. A phage display system for detection of $\mathrm{T}$ cell receptor-antigen interactions. Mol. Immunol. 32:1387-1397.

114.Ossendorp, F., E. Mengede, M. Camps, R. Filius, and C.J. Melief. 1998. Specific T helper cell requirement for optimal induction of cytotoxic T lymphocytes against major histocompatibility complex class II negative tumors. J. Exp. Med. 187:693-702.

115.Overwijk, W.W., D.S. Lee, D.R. Surman, K.R. Irvine, C.E. Touloukian, C.C. Chan, M.W. Carroll, B. Moss, S.A. Rosenberg, and N.P. Restifo. 1999. Vaccination with a recombinant vaccinia virus encoding a "self" antigen induces autoimmune vitiligo and tumor cell destruction in mice: requirement for CD4(+) T lymphocytes. Proc. Natl. Acad. Sci. USA 96:2982-2987.

116.Overwijk, W.W., M.R. Theoret, and N.P. Restifo. 2000. The future of interleukin-2: enhancing therapeutic anticancer vaccines. Cancer J. Sci. Am. 6(Suppl 1):S76-S80.

117.Paradiso, P.R. and A.A. Lindberg. 1996. Glycoconjugate vaccines: future combinations. Dev. Biol. Stand. 87:269-275.

118.Pardoll, D.M. 1999. Inducing autoimmune disease to treat cancer. Proc. Natl. Acad. Sci. USA 96:5340-5342.

119.Pardoll, D.M. 2000. Therapeutic vaccination for cancer. Clin. Immunol. 95(1 Pt 2):S44S62.

120.Pardoll, D.M. and S.L. Topalian. 1998. The role of CD4+ T cell responses in antitumor immunity. Curr. Opin. Immunol. 10:588594.

121.Pellegrini, P., A.M. Berghella, T. Del Beato, S. Cicia, D. Adorno, and C.U. Casciani. 1996. Disregulation in TH1 and TH2 subsets of CD4+ T cells in peripheral blood of colorectal cancer patients and involvement in cancer establishment and progression. Cancer Immunol. Immunother. 42:1-8.

122.Perez-Diez, A., A. Martinez-Crespo, L.A. Perez-Mediavilla, E. Santiago, and N. Lopez-Moratalla. 2000. Immunoregulating properties of peptides related to tumor rejection antigens: effect on human monocytes and natural killer cells. J. Immunother. 23:215224.

123.Pettit, S.J., K. Seymour, E. O'Flaherty, and J.A. Kirby. 2000. Immune selection in neoplasia: towards a microevolutionary model of cancer development. Br. J. Cancer 82:1900-1906.

124.Phalipon, A., A. Folgori, J. Arondel, G. Sgaramella, P. Fortugno, R. Cortese, P.J. Sansonetti, and F. Felici. 1997. Induction of anti-carbohydrate antibodies by phage li- 
brary-selected peptide mimics. Eur. J. Immunol. 27:2620-2625.

125.Philip, R., S.E. Alters, E. Brunette, J. Ashton, J. Gadea, J. Yau, J. Lebkowski, and M. Philip. 2000. Dendritic cells loaded with MART-1 peptide or infected with adenoviral construct are functionally equivalent in the induction of tumor-specific cytotoxic T lymphocyte responses in patients with melanoma. J. Immunother. 23:168-176.

126.Piccart, M.J., L. Biganzoli, and J.A. Roy. 1996. Adjuvant systemic therapy for breast cancer. Curr. Opin. Oncol. 8:478-484.

127.Piccart, M. J., and G. N. Hortobagyi. 1997. Conclusions: future strategies in the treatment of breast cancer. Semin. Oncol. 24(1 Suppl 3):534-540.

128.Pincus, S.H., M.J. Smith, H.J. Jennings, J.B. Burritt, and P.M. Glee. 1998. Peptides that mimic the group B streptococcal type III capsular polysaccharide antigen. J. Immunol. 160:293-298.

129.Pulaski, B.A., and S. Ostrand-Rosenberg. 1998. Reduction of established spontaneous mammary carcinoma metastases following immunotherapy with major histocompatibility complex class II and B7.1 cell-based tumor vaccines. Cancer Res. 58:1486-1493.

130.Qiu, J., P. Luo, K. Wasmund, Z. Steplewski, and T. Kieber-Emmons. 1999. Towards the development of peptide mimotopes of carbohydrate antigens as cancer vaccines. Hybridoma 18:103-112.

131.Ragupathi, G., L. Howard, S. Cappello, R.R. Koganty, D. Qiu, B.M. Longenecker, M.A. Reddish, K.O. Lloyd, and P.O. Livingston. 1999. Vaccines prepared with sialyl$\mathrm{Tn}$ and sialyl-Tn trimers using the 4-(4maleimidomethyl)cyclohexane-1-carboxyl hydrazide linker group result in optimal antibody titers against ovine submaxillary mucin and sialyl-Tn-positive tumor cells. Cancer Immunol. Immunother. 48:1-8.

132.Reddish, M.A., G.D. MacLean, S. Poppema, A. Berg, and B.M. Longenecker. 1996. Pre-immunotherapy serum CA27.29 (MUC1) mucin level and CD69+ lymphocytes correlate with effects of Theratope sialyl-Tn$\mathrm{KLH}$ cancer vaccine in active specific immunotherapy. Cancer Immunol. Immunother. 42:303-309.

133.Reed, E.C. 1996. Systemic adjuvant therapy for breast cancer. Nebr. Med. J. 81:48-50.

134.Restifo, N.P., H. Ying, L. Hwang, and W.W. Leitner. 2000. The promise of nucleic acid vaccines. Gene Ther. 7:89-92.

135.Ribas, A., L.H. Butterfield, B. Hu, V.B. Dissette, A.Y. Chen, A. Koh, S.N. Amarnani, J.A. Glaspy, W.H. McBride, and J.S. Economou. 2000. Generation of T-cell immunity to a murine melanoma using MART1-engineered dendritic cells. J. Immunother. 23:59-66.

136.Rieser, C., R. Ramoner, L. Holtl, H. Rogatsch, C. Papesh, A. Stenzl, G. Bartsch, and M. Thurnher. 2000. Mature dendritic cells induce T-helper type-1-dominant immune responses in patients with metastatic renal cell carcinoma. Urol. Int. 63:151-159.

137.Riker, A.I., U.S. Kammula, M.C. Panelli, E. Wang, G.A. Ohnmacht, S.M. Steinberg, S.A. Rosenberg, and F.M. Marincola. 2000.
Threshold levels of gene expression of the melanoma antigen gp100 correlate with tumor cell recognition by cytotoxic $\mathrm{T}$ lymphocytes. Int. J. Cancer. 86:818-826.

138.Russo, V., S. Tanzarella, P. Dalerba, D. Rigatti, P. Rovere, A. Villa, C. Bordignon, and C. Traversari. 2000. Dendritic cells acquire the MAGE-3 human tumor antigen from apoptotic cells and induce a class I-restricted T cell response. Proc. Natl. Acad. Sci. USA. 97:2185-2190.

139.Samonigg, H., M. Wilders-Truschnig, I. Kuss, R. Plot, H. Stoger, M. Schmid, T. Bauernhofer, A. Tiran, T. Pieber, L. Havelec, and H. Loibner. 1999. A double-blind randomized-phase II trial comparing immunization with antiidiotype goat antibody vaccine SCV 106 versus unspecific goat antibodies in patients with metastatic colorectal cancer. J. Immunother. 22:481-488.

140.Sandmaier, B.M., D.V. Oparin, L.A. Holmberg, M.A. Reddish, G.D. MacLean, and B.M. Longenecker. 1999. Evidence of a cellular immune response against sialyl-Tn in breast and ovarian cancer patients after highdose chemotherapy, stem cell rescue, and immunization with Theratope STn-KLH cancer vaccine. J. Immunother. 22:54-66.

141.Schlaak, J.F., C. Claus, K.H. Meyer zum Buschenfelde, and W. Dippold. 1995. AntiGD3 antibodies are potent activators of human gamma/delta and alpha/beta positive $\mathrm{T}$ cells. Scand. J. Immunol. 41:475-480

142.Schlom, J. and J.W. Hodge. 1999. The diversity of T-cell co-stimulation in the induction of antitumor immunity. Immunol Rev. 170:73-84

143.Schultes, B.C., R.P. Baum, A. Niesen, A.A. Noujaim, and R. Madiyalakan. 1998. Antiidiotype induction therapy: anti-CA125 antibodies (Ab3) mediated tumor killing in patients treated with Ovarex mAb B43.13 (Ab1). Cancer Immunol. Immunother. 46: 201-212.

144.Schwaab, T., J.A. Heaney, A.R. Schned, R.D. Harris, B.F. Cole, R.J. Noelle, D.M. Phillips, L. Stempkowski, and M.S. Ernstoff. 2000. A randomized phase II trial comparing two different sequence combinations of autologous vaccine and human recombinant interferon gamma and human recombinant interferon alpha2B therapy in patients with metastatic renal cell carcinoma: clinical outcome and analysis of immunological parameters. J. Urol. 163:1322-1327.

145.Sette, A. and J. Sidney. 1998. HLA supertypes and supermotifs: a functional perspective on HLA polymorphism. Curr. Opin. Immunol. 10:478-482.

146.Shan, D., J.A. Ledbetter, and O.W. Press. 2000. Signaling events involved in antiCD20-induced apoptosis of malignant human $B$ cells. Cancer Immunol. Immunother. 48:673-683.

147.Shevach, E.M. 2000. Regulatory T cells in autoimmmunity. Annu. Rev. Immunol. 18:423-449.

148.Shoham, J., R. Hirsch, Z. Zakay-Rones, M.E. Osband, and H.J. Brennert. 1990 Augmentation of tumor cell immunogenicity by viruses-an approach to specific immunotherapy of cancer. Nat. Immun. Cell
Growth Regul. 9:165-172.

149.Sinkovics, J.G., and J.C. Horvath. 2000. Vaccination against human cancers (review). Int J. Oncol. 16:81-96.

150.Sioud, M., M. Hansen, and A. Dybwad. 2000. Profiling the immune responses in patient sera with peptide and cDNA display libraries. Int. J. Mol. Med. 6:123-128.

151.Slingluff, C.L. 1999. Targeting unique tumor antigens and modulating the cytokine environment may improve immunotherapy for tumors with immune escape mechanisms. Cancer Immunol. Immunother. 48:371-373.

152.Slovin, S.F., G. Ragupathi, S. Adluri, G. Ungers, K. Terry, S. Kim, M. Spassova, W.G. Bornmann et al. 1999. Carbohydrate vaccines in cancer: immunogenicity of a fully synthetic globo $\mathrm{H}$ hexasaccharide conjugate in man. Proc. Natl. Acad. Sci. USA 96:57105715.

153.Song, K., Y. Chang, and G.J. Prud'homme. 2000. Regulation of T-helper-1 versus Thelper-2 activity and enhancement of tumor immunity by combined DNA-based vaccination and nonviral cytokine gene transfer. Gene Ther. 7:481-492.

154.Springer, G.F. 1984. T and Tn, general carcinoma autoantigens. Science 224:11981206.

155.Srivastava, P.K. 1997. Purification of heat shock protein-peptide complexes for use in vaccination against cancers and intracellular pathogens. Methods 12:165-171.

156.Stebbing, J., E. Copson, and S. O'Reilly. 2000. Herceptin (trastuzamab) in advanced breast cancer. Cancer Treat. Rev. 26:287-290.

157.Stevenson, F.K. 1999. DNA vaccines against cancer: from genes to therapy. Ann. Oncol. 10:1413-1418.

158.Sugita, M., D.B. Moody, R.M. Jackman, E.P. Grant, J.P. Rosat, S.M. Behar, P.J. Peters, S.A. Porcelli, and M.B. Brenner. 1998. CD1 - a new paradigm for antigen presentation and $\mathrm{T}$ cell activation. Clin. Immunol. Immunopathol. 87:8-14.

159.Syrigos, K.N., A.J. Karayiannakis, and A. Zbar. 1999. Mucins as immunogenic targets in cancer. Anticancer Res. 19:5239-5244.

160.Taki, T., D. Ishikawa, H. Hamasaki, and S. Handa. 1997. Preparation of peptides which mimic glycosphingolipids by using phage peptide library and their modulation on beta-galactosidase activity. FEBS Lett. 418:219-223.

161.Tarte, K. and B. Klein. 1999. Dendritic cell-based vaccine: a promising approach for cancer immunotherapy. Leukemia 13:653663.

162.Thurner, B., I. Haendle, C. Roder, D. Dieckmann, P. Keikavoussi, H. Jonuleit, A. Bender, C. Maczek et al. 1999. Vaccination with mage-3A1 peptide-pulsed mature, monocyte-derived dendritic cells expands specific cytotoxic $\mathrm{T}$ cells and induces regression of some metastases in advanced stage IV melanoma. J. Exp. Med. 190:1669-1678.

163.Titzer, S., O. Christensen, O. Manzke, H. Tesch, J. Wolf, B. Emmerich, C. Carsten, V. Diehl, and H. Bohlen. 2000. Vaccination of multiple myeloma patients with idiotypepulsed dendritic cells: immunological and clinical aspects. Br. J. Haematol. 108:805- 
816.

164.Tseng, S.H., C.L. Hsieh, S.M. Lin, and L.H. Hwang. 1999. Regression of orthotopic brain tumors by cytokine-assisted tumor vaccines primed in the brain. Cancer Gene Ther. 6:302-312.

165.Tureci, O., U. Sahin, and M. Pfreundschuh. 1997. Serological analysis of human tumor antigens: molecular definition and implications. Mol. Med. Today 3:342-349.

166.Valadon, P., G. Nussbaum, L.F. Boyd, D.H. Margulies, and M.D. Scharff. 1996. Peptide libraries define the fine specificity of anti-polysaccharide antibodies to Cryptococcus neoformans. J. Mol. Biol. 261:11-22.

167.Vanaja, D.K., M.E. Grossmann, E. Celis, and C.Y. Young. 2000. Tumor prevention and antitumor immunity with heat shock protein 70 induced by 15-deoxy-delta12,14prostaglandin $\mathrm{J} 2$ in transgenic adenocarcinoma of mouse prostate cells. Cancer Res. 60:4714-4718.

168.Vermorken, J.B., A.M. Claessen, H. van Tinteren, H.E. Gall, R. Ezinga, S. Meijer, R.J. Scheper, C.J. Meijer et al. 1999. Active specific immunotherapy for stage II and stage III human colon cancer: a randomised trial. Lancet 353:345-350.

169.Wagner, U., S. Kohler, G. Prietl, P. Giffels, S. Schmidt-Nicolai, H. Schlebusch, U. Grunn, H. Bender et al. 1999. [Monoclonal anti-idiotype antibodies in immunotherapy of ovarian carcinoma (MAb ACA125) and breast carcinoma (MAb ACA14C5)]. Zentralbl. Gynakol. 121:190-195.

170.Wang, X.Y., Y. Kaneko, E. Repasky, and J.R. Subjeck. 2000. Heat shock proteins and cancer immunotherapy. Immunol. Invest. 29:131-137.

171.Weber, J.S., F.L. Hua, L. Spears, V. Marty, C. Kuniyoshi, and E. Celis. 1999. A phase I trial of an HLA-A1 restricted MAGE3 epitope peptide with incomplete Freund's adjuvant in patients with resected high-risk melanoma. J. Immunother. 22:431-440.

172.Weiner, G.J., H.M. Liu, J.E. Wooldridge, C.E. Dahle, and A.M. Krieg. 1997. Immunostimulatory oligodeoxynucleotides containing the CpG motif are effective as immune adjuvants in tumor antigen immunization. Proc. Natl. Acad. Sci. USA. 94:10833-10837.

173.Wells, A.D. and M. Malkovsky. 2000. Heat shock proteins, tumor immunogenicity and antigen presentation: an integrated view. Immunol. Today 21:129-132.

174.Westerink, M.A.J., P.C. Giardina, M.A. Apicella, and T. Kieber-Emmons. 1995. Peptide mimicry of the meningococcal group C capsular polysaccharide. Proc. Natl. Acad. Sci. USA 92:4021-4025.

175.Wu, W.Z., K.D. Liu, Q. Xie, and H.S. Wu. 1999. The study on the expression of membrane HSP70 protein in H22 cell and its immunoprotective mechanism against carcinoma. J Exp. Clin. Cancer Res. 18:543-548.

176.Xiang, R., H.N. Lode, T.H. Chao, J.M. Ruehlmann, C.S. Dolman, F. Rodriguez, J.L. Whitton, W.W. Overwijk, N.P. Restifo, and R.A. Reisfeld. 2000. An autologous oral DNA vaccine protects against murine melanoma. Proc. Natl. Acad. Sci. USA. 97:5492-
5597.

177.Yang, S., C.E. Vervaert, H.F. Seigler, and T.L. Darrow. 1999. Tumor cells cotransduced with B7.1 and gamma-IFN induce effective rejection of established parental tumor. Gene Ther. 6:253-262.

178.Zhang, H., S. Zhang, N.K. Cheung, G. Ragupathi, and P.O. Livingston. 1998. Antibodies against GD2 ganglioside can eradicate syngeneic cancer micrometastases. Cancer Res. 58:2844-2849.

179.Zhang, H., Z. Zhong, and L.A. Pirofski. 1997. Peptide epitopes recognized by a human anti-cryptococcal glucuronoxylomannan antibody. Infect. Immun. 65:1158-1164.

Received 7 August 2000; accepted 10 October 2000.

\section{Address correspondence to:}

Dr. Thomas Kieber-Emmons

Department of Pathology and Laboratory Medicine

Room 205, John Morgan Building

36th and Hamilton Walk

Philadelphia, PA 19104-6082, USA

e-mail: tom@xray.med.upenn.edu 